9. Communication from the Commission «Guidelines on State aid for environmental protection and energy 2014-2020» (2014/C 200/01). Official Journal of the European Union. 28 March 2014. C. 200. Pp. 1-55. URL: https://eur-lex.europa.eu/legal-content/EN/TXT/PDF/?uri=CELEX: 52014XC0628(01)\&from=EN (access date: 21.02.2021)

DOI https://doi.org/10.30525/978-9934-26-045-2-23

\title{
ОСОБЛИВОСТІ ЗАКОНОДАВЧОГО ЗАБЕЗПЕЧЕННЯ РЕАЛІЗАЦІЇ ДЕРЖАВНО-ПРИВАТНОГО ПАРТНЕРСТВА: ПРОБЛЕМИ ТА ПЕРСПЕКТИВИ
}

\author{
Палажченко К. С. \\ аспірантка кафедри теорії та практики управління \\ Начіонального технічного університету України \\ «Киїський політехнічний інститут імені Ігоря Сікорського» \\ м. Київ, Україна
}

Полеміка щодо питань альтернативних форм фінансування суспільно значущих проектів, протягом останнього десятиліття набирає все більшої актуальності і імперативно пов'язано 3 інноваційними процеси, які відіграють вирішальну роль у контексті розвитку економіки України. Саме тому, важливим завданням виступає дослідження та впровадження передових форм, механізмів та моделей, що мають на меті підвищення ефективності виробництва та надання соціальних та інфраструктурних послуг. Однією 3 альтернатив розвитку визначальних галузей економіки та зменшення фінансового навантаження на бюджет є механізм державно-приватного партнерства (далі - «ДПП»). Позитивна практика поєднання роботи державних і приватних структур може стати каталізатором змін, врахувавши не лише інтереси держави, а й інших учасників ДПП: бізнесових структур та інших стейкколдерів.

Модель співпраці держави та бізнес структур успішно функціонує у багатьох розвинених країнах світу та дає змогу підвищити ефективність використання об'єктів державної власності на основі використання ресурсів приватного сектору.В умовах дефіциту державного бюджету розвиток такої моделі співпраці $\epsilon$ важливим завданням для України. Початок впровадження взаємодії державного та приватного секторів економіки в Україні розпочався із встановленням 
концесійного Законодавства у 1999 році і передувало іншим країнам СНД, які сьогодні мають широку базу успішно реалізованих проектів ДПП. Наступним кроком до покращення взаємодії держави та приватного сектору в Україні стало впровадження у 2010 році Закону України «Про державно-приватне партнерство» (далі - «Закон про ДПП») [1]. Наміри Уряду України розширити можливості та повноваження держваного та приватного партнерів 3 метою збільшення інвестиційної привабливості відобразились у розробці Закону України «Про внесення змін до деяких законів України щодо усунення регуляторних бар'єрів для розвитку державно-приватного партнерства та стимулювання інвестицій в Україні» від 24.11.2015 та інших підзаконних актів Уряду щодо проведення аналізу ефективності проектів, аналізу та оцінки ризиків, конкурсних процедур, заміни приватного партнера [2]. Зважаючи на статистичні дані Мінекономрозвитку України, кількість угод, які реалізуються на засадах ДПП щорічно збільшуються, однак динаміка не є задовільною - із сотень зареєстрованих проектів ДПП в Україні реалізується та знаходиться на стадіях підготовки невелика кількість. Конкретніше, за даними центральних та місцевих органів виконавчої влади в Україні станом на 01січня2020 року на засадах ДПП укладено 187 договорів. Із зазначеної кількості договорів реалізується лише частина. За 2020 рік - 52 договори (34 - договорів концесії, 16 - договорів про спільну діяльність, 2 - інші договори), 135 договори не реалізується (4 договори закінчено термін дії, 18 договорів - розірвано, 113 договорів не виконується) [3].

Незначна кількість реалізованих проектів ДПП в Україні вказує на несформовану логічну систему відносин держави, бізнес структур та соціуму. Хоча, в Україні існує широкий спектр активів, які у поєднанні 3 достатнім інституційним забезпеченням співпраці державного та приватного секторів та маржинальністю ринку могли б бути потенційно привабливими для інвестицій з боку бізнес структур. Для створення сприятливих умов реалізації кейсів ДПП та покращення інвестиційного середовища вважаємо необхідним визначити гальмуючі чинники, що впливають на динаміку розвитку проектів, які реалізуються на засадах співпраці державного та приватного секторів. Для цього пропонуємо порівняти профільний Закон України у сфері державноприватних відносин - Закон про ДПП та прийнятий Міжпарламентською асамблеєю країн СНД Модельний закон про публічно-приватне партнерство. 


\section{Компаративний аналіз Закону України «Про державно-приватне партнерство»} та Модельного закону про публічно-приватне партнерство

\begin{tabular}{|c|c|c|}
\hline Назва закону & $\begin{array}{c}\text { Закон України «Про } \\
\text { державно-приватне } \\
\text { партнерство» }\end{array}$ & $\begin{array}{c}\text { Модельний закон про } \\
\text { публічно-приватне } \\
\text { партнерство }\end{array}$ \\
\hline Термін & $\begin{array}{l}\text { державно-приватне } \\
\text { партнерство (ДПП) }\end{array}$ & $\begin{array}{c}\text { публічно-приватне } \\
\text { партнерство (ППП) }\end{array}$ \\
\hline $\begin{array}{c}\text { Форми та моделі } \\
\text { реалізації партнерства }\end{array}$ & $\begin{array}{c}\text { Концесія виступає } \\
\text { основною формою } \\
\text { реалізації ДПП }\end{array}$ & $\begin{array}{c}\text { Механізм реалізації ППП } \\
\text { побудован на принципі } \\
\text { діалогу між партнерами } \\
\text { та знаходженні } \\
\text { оптимальних рішень } \\
\text { щодо форм та моделей } \\
\text { ППП для публічного та } \\
\text { приватного сектору. } \\
\text { Використовується угода } \\
\text { ППП та інші варіанти, о } \\
\text { не суперечать } \\
\text { законодавству, } \\
\text { використовуються і } \\
\text { міжнародні договори, } \\
\text { забезпечуючи додаткові } \\
\text { надходження від } \\
\text { іноземних партнерів }\end{array}$ \\
\hline Характер договору & Має жорсткі рамки & $\begin{array}{c}\text { Договір має лише } \\
\text { рекомендаційний } \\
\text { характер } \\
\end{array}$ \\
\hline $\begin{array}{c}\text { Особливості } \\
\text { проведення конкурсу }\end{array}$ & $\begin{array}{c}\text { Партнером може стати } \\
\text { новостворене або без } \\
\text { досвіду реалізації } \\
\text { конкретних проектів } \\
\text { підприємство. Основним } \\
\text { критерієм вибору } \\
\text { приватного партнера (не } \\
\text { суперечить Закону вибір } \\
\text { компанії без зареєстро- } \\
\text { ваної юридичної особи, } \\
\text { тобто спільної діяльності) } \\
\text { є іï фінансова перевага } \\
\text { над конкурентами } \\
\text { на час розгляду. }\end{array}$ & $\begin{array}{c}\text { Конкурсна процедура } \\
\text { забезпечує можливість } \\
\text { діалогу між партнерами, } \\
\text { що допомагає зрозуміти } \\
\text { мету та майбутній напрям } \\
\text { роботи партнерів, } \\
\text { обговорити та знайти } \\
\text { компроміс щодо певних } \\
\text { загроз та обставин, які } \\
\text { можуть виникнути в } \\
\text { процесі реалізації проекту } \\
\text { до його початку }\end{array}$ \\
\hline
\end{tabular}


Продовження таблиці 1

\begin{tabular}{|c|c|c|}
\hline $\begin{array}{c}\text { Ризики для приватного } \\
\text { партнера }\end{array}$ & $\begin{array}{c}\text { Закон забезпечує } \\
\text { мінімізацію ризиків для } \\
\text { державного партнера. } \\
\text { Для приватного партнера } \\
\text { декларується відсутність } \\
\text { гарантій виконання } \\
\text { державних зобов’язань в } \\
\text { рамках ДПП }\end{array}$ & $\begin{array}{c}\text { Приватний партнер } \\
\text { захищен механізмом } \\
\text { передачі права власності } \\
\text { на об'єкт до кінця } \\
\text { терміну до горову ППП } \\
\text { або виконання своїх } \\
\text { зобов’язань зі сторони } \\
\text { державного партнера }\end{array}$ \\
\hline $\begin{array}{c}\text { Процедура прийняття } \\
\text { рішень щодо } \\
\text { доцільності реалізації } \\
\text { проекту ДПП }\end{array}$ & $\begin{array}{c}\text { Відповідно до Закону } \\
\text { передбачена процедура } \\
\text { прийняття рішень щодо } \\
\text { доцільності реалізації } \\
\text { проекту ДПП, однак, } \\
\text { вона є складною і не } \\
\text { потребує залучення та } \\
\text { узгодження рішень } \\
\text { разом із ОТГ, відсутнє } \\
\text { положення про } \\
\text { громадські слухання та } \\
\text { фінансово-правове } \\
\text { обгрунтування проекту }\end{array}$ & $\begin{array}{c}\text { Обов'язковою мірою є } \\
\text { фінансово-правове } \\
\text { обгрунтування проекту } \\
\text { ППП, включаючи } \\
\text { громадянські слухання із } \\
\text { залученням } \\
\text { представників ОТГ. } \\
\text { Підтримуються } \\
\text { висловлення міркувань } \\
\text { щодо доцільності } \\
\text { реалізації проекту в } \\
\text { рамках ППП }\end{array}$ \\
\hline $\begin{array}{c}\text { Залучення фінансових } \\
\text { організацій }\end{array}$ & $\begin{array}{c}\text { Залучення фінансових } \\
\text { організацій } \\
\text { практикується на протязі } \\
\text { малого проміжку часу та } \\
\text { процедура не } є \\
\text { досконалою, тому } \\
\text { використання такої } \\
\text { можливості } \\
\text { уповільнюється за } \\
\text { рахунок складності } \\
\end{array}$ & $\begin{array}{c}\text { Фінансові організації } \\
\text { активно долучаються до } \\
\text { проектів ППП і, } \\
\text { безпосередньо, є його } \\
\text { учасниками }\end{array}$ \\
\hline Фінансові зобов'язання & $\begin{array}{c}\text { Розглядаються } \\
\text { опосередковано і прямо } \\
\text { не регулює фінансові } \\
\text { відносини між } \\
\text { партнерами зменшуючи } \\
\text { інтерес і привабливість } \\
\text { проекту для інвестицій з } \\
\text { боку приватного } \\
\text { партнера }\end{array}$ & $\begin{array}{c}\text { Фінансові відносини } \\
\text { розкрито в повній мірі і } \\
\text { передбачає різні підходи } \\
\text { до формування } \\
\text { фінансових відносин } \\
\text { партнерів та населенням. } \\
\text { Такий підхід зумовлює } \\
\text { мінімізацію фінансових } \\
\text { ризиків для партнерів та } \\
\text { стимулює реалізацію } \\
\text { проектів у сфері } \\
\text { інфраструктури }\end{array}$ \\
\hline
\end{tabular}

Джерело складено автором на основі : [1; 4] 
Отже, прийняття дієвої законодавчої бази у сфері ДПП, своєчасне внесення змін у діючі закони, а також реалізація вже прийнятих законів - актуальне, важливе і складне державне завдання. А положення Модельного закону про публічно-приватне партнерство можуть мати рекомендаційний характер щодо забезпечення достатньої та прогресивної нормативно-правової бази ДПП для позитивної динаміки розвитку проектів ДПП та покращення інвестиційного клімату в Україні.

\section{Література:}

1. Про державно-приватне партнерство: Закон України від 01.07.2010 № 2404-VI. Дата оновлення: 25.10.2020 URL: http://zakon3.rada.gov.ua/laws/show/2404-17 (дата звернення: 25.02.2021)

2. Про внесення змін до деяких законів України щодо усунення регуляторних бар'єрів для розвитку державно-приватного партнерства та стимулювання інвестицій в Україні: Закон України від 24.11.2015 № 817-VIII. Дата оновлення 01.02.2020. URL: zakon.rada.gov.ua/ laws/show/817-19/ (дата звернення: 22.12.2020)

3. Стан здійснення ДПП. Офіційний сайт Міністерства економічного розвитку, торгівлі та сільського господарства України. URL: https://www.me.gov.ua/Search/Result?lang=uk-UA\&isSpecial=True\& query $=\% 25 \mathrm{~d} 0 \% 25 \mathrm{a} 1 \% 25 \mathrm{~d} 0 \% 25 \mathrm{a} 2 \% 25 \mathrm{~d} 0 \% 2590 \% 25 \mathrm{~d} 0 \% 259 \mathrm{~d} \% 2 \mathrm{~B} \% 25 \mathrm{~d} 0$ $\% 2597 \% 25 \mathrm{~d} 0 \% 2594 \% 25 \mathrm{~d} 0 \% 2586 \% 25 \mathrm{~d} 0 \% 2599 \% 25 \mathrm{~d} 0 \% 25 \mathrm{a} 1 \% 25 \mathrm{~d} 0 \% 259$ $\mathrm{d} \% 25 \mathrm{~d} 0 \% 2595 \% 25 \mathrm{~d} 0 \% 259 \mathrm{~d} \% 25 \mathrm{~d} 0 \% 259 \mathrm{~d} \% 25 \mathrm{~d} 0 \% 25 \mathrm{af} \% 2 \mathrm{~B} \% 25 \mathrm{~d} 0 \% 25 \mathrm{~b} 4$ $\% 25 \mathrm{~d} 0 \% 25 \mathrm{bf} \% 25 \mathrm{~d} 0 \% 25 \mathrm{bf}$ (дата звернення: 26.02.2021)

4. О публично-частном партнерстве: модельный закон. Приложение к постановлению МПА СНГ, 28 ноября 2014 г., № 41-9. URL: http://www.parliament.am/library/modelayin\%20orenqner/305.pdf. (Дата доступа: 01.03.2021). 